\title{
THE SELF AS OBJECT IN CRITICAL READINGS OF JANE EYRE
}

Lauren Smith

"TO TELL ONE'S story is to present one's self . . .," begins Helen von Schmidt in an article comparing Dickens and Brontë. "To tell one's story is also to create the self one presents, to do so by the very choices one makes in the telling...," she continues, and then goes on to assert that both Jane Eyre and Great Expectations are novels in which a self is created (von Schmidt 84). Behind von Schmidt's thoughts on Dickens and Brontë are two related and problematic ideas about selfhood. The first is that there is such a thing as a self which can be "presented" by an author to an audience. It assumes that an author can know what she/he is, can see clearly her/his own behavior, motivations, character. The second assumption is that the author also "creates" her/his "self" in the process of writing. This assumption is more acceptable because it makes room for the unknowable, the unconscious that might be located in the "gaps" and "indeterminacies" of the text. Still, however, she reveals a fundamental belief that by the end of the text something must be formed which is whole. The self is treated like a product, something to be arrived at by the end of the production process, the story.

Inasmuch as von Schmidt's use of the word "self" does still attempt to engage us in a discussion about what self is, how it exists in relation to the world, etc., it is useful. The problem with her vision is that it inspires her to make evaluative statements which are not necessarily fair or, more importantly, helpful. Is the self here a whole self? Is it an integrated self? Or is it immature (read: sick)? These are the questions von Schmidt is really asking. "Jane Eyre and Great Expectations offer two almost wholly opposite models of the self and its relation to the world," she says, making her self-as-object perspective quite clear and implying that our selves too are objects that can be modeled on template fictional selves. "However one honors them separately as 
great texts, finally, it seems, one is asked to choose one of the two exempla the novels offer" (84). In other words, we are to choose which template we would like to use in the production of our own selves.

One of the problems with the self-as-product perspective is that it encourages an evaluation which ignores the contexts within which it was and is read. I was going to say that such a reading is apolitical, but this is not true. To evaluate a work outside of context is to evaluate it according to some abstract principle, that is, to compare it to some ideal and judge it accordingly. Not only is the process of choosing the "right" ideal completely arbitrary, but in choosing an idea the writer sets up a system whereby texts (and readings of texts) are arranged in a hierarchy based on their proximity to that ideal.

The vision of the healthy, mature self as a whole, relatively fixed thing manifests itself to varying degrees in all the critical texts I will explore in the paper. I would like to reveal how these critics are "drenched" (Adrienne Rich's term) in patriarchal (normative, product-oriented) ideas about self, and to, as Schweickart suggests, "[take] the part of the woman writer against patriarchal readings that trivialize or distort her work" (Schweickart 46).

Perhaps my motivation for beginning my critique of readings with von Schmidt comes from my own bias. I love the book Jane Eyre and only like and admire Great Expectations; whereas von Schmidt finds only Great Expectations truly admirable. The reasons for her evaluation have to do with the "models of the self" presented in the two novels (von Schmidt 84). In the beginnings of the two works, she argues, the main characters are in much the same sort of position. Both of them are orphans living with "figures we recognize as 'the wicked stepmother"; neither knows who her/his real parents are (85). Pip attempts immediately to make connections. He spends a lot of time imagining what his parents are like and creates an imaginary relationship with them (85). Furthermore, he is able, from the very beginning of his story, to establish the possibility of connection with such "evil" characters as Magwitch and Miss Havisham by seeing their humanness-and in the end of the story, to actually bring these connections about. "Pip," according to von Schmidt, "insists that the self is created in relation to others and by the nature of that relation" (86).

Jane's self, however, is not "created in relation." Most of the characters in Jane Eyre have "no life of their own; they exist solely as figures against whom Jane can assert her own identity" (von Schmidt 86). Little Jane does not search for connection. She does not seem, for example, to be interested in learning anything about her dead parents; at the Reeds' house, she is most happy alone and wrapped up 
in her own imaginings. In fact, "the climate of her real world ... has less interest for her than the climate she absorbs, indeed chooses, in the book she is reading. ..." (85). Unlike Pip, Jane is never able to transcend her history to establish connection with those who have done her evil-namely Mrs. Reed and her children (87).

The self created in Jane Eyre is a failure, according to von Schmidt. The criteria by which she judges Jane Eyre's self is one that has to do with the ability to connect with others and to accept society. The ideal self is the one that can, like Pip, "move into a wider world and share an ordinary life" (von Schmidt 90). However, at the end of Charlotte Brontë's novel, the heroine is isolated and full of "self-division" (88). What von Schmidt has forgotten in her eagerness to measure the two works according to one universal criterion, however, is that Dickens was a man creating a male character, and Brontë was a woman creating a female character. Ordinary life for Jane Eyre would have been stultifying. Whereas Pip could create himself in relation to society and other people, Jane could not. The available pool of roles, definitions, possibilities for action was unacceptable. If Jane could not "admit the presence of any other valid voice" (von Schmidt, p. 91), it was because she could not listen to any other voice and survive.

There is something very attractive about Nina Auerbach's approach to the self in Jane Eyre. It is dramatic: "The self is born in [Brontë's] novels out of a clash of extreme and opposing forces. ..." (Auerbach 328). And it is dynamic. Auerbach focuses on the struggle, the "unresolved dialectic" of Charlotte Brontë's mind reflected in images of fire and ice (326). "Jane Eyre," according to Auerbach, "is a double character. ..." (330).

The governess side of Jane, she argues, the demure and dutiful side, is represented by ice. This is the Jane who represses or simply is without feeling - the "frozen child" who can admit freely that she does not love the Reeds (Auerbach 331). This is also the side of Jane that is represented by religious persons and institutions in the storynotably Lowood and St. John (332), and even Helen Burns and Miss Temple. Auerbach sees this repressive force as continually threatening takeover. It is in Jane Eyre's "struggle" with St. John that the danger is most obvious and pressing - probably because "his ice is in [her]" (334). He is her cousin, part of the family she was deprived of as a child, and of all the forces of ice, he is most capable of winning her over.

Fire, Auerbach goes on to say, represents the feeling side of Jane. It is the part of her personality with which she paints passionate and surreal landscapes, the part which addresses and frightens Mrs. Reed, the part she sees in the red room mirror and is herself frightened by. 
Despite Jane's demure carriage in her post as governess, Rochester sees and loves this part of Jane calling her a "firespirit" (Jane Eyre 270). Again, Auerbach sees many of the things in Jane's environment as simply extensions or projections of Jane's fiery self. Mr. Rochester and Thornfield are, for example, representatives of fire. Despite the destructive role fire plays in Jane Eyre, Auerbach seems to find the fiery side of Jane's personality more attractive, more healthy, and associated with imagination in a way that she does not explain. Furthermore, she finds in Jane's marriage and in the pious life she and Edward live at Ferndean a triumph of the forces of ice. Writes Auerbach, "our final sense of the book is that 'reality' is 'imagination' broken and blind" (335). In Auerbach's eyes this is tragic.

Auerbach's exploration of the fire and ice imagery in Jane Eyre is limited because she attempts to understand everything about Jane's character, Jane's self, in these terms. Jane therefore can be only a two-sided creature - either emotional or "cold" (Auerbach 330). Jane's spirituality can only be seen in terms of coldness, ice, emotionlessness; and, possibly more disturbing, no distinction can be made between Jane's anger and her love for Edward Rochester, which are both seen as expressions of her fiery side. Such confusion between anger and sexuality obscures the true nature of both. Furthermore, it suggests that Charlotte Brontë connects the two things in her writing. This is not accurate; although Edward is, as Auerbach points out, said to have a "flaming glance" and although Jane and Edward's relationship is very intense, it is more often described in spiritual terms, or in terms of magic and fairies, than in the language of fire. When Rochester, for example, tells the story of his love for Jane to Adele, Jane becomes a fairy and the wedding ring becomes a talisman with which Rochester can follow her to the moon (Jane Eyre 275-76).

Another problem is that Auerbach's vision of the self as composed of two conflicting forces prevents her from seeing Jane's feelings as a response to her environment. Jane does not fall in love with Edward, but simply finds him an occasion for the expression of passion. She does not get angry at or because of something, she simply is angry, and that anger is expressed in the episode in the red room and at Thornfield in the person of Bertha Mason. In fact, according to Auerbach, there is no environment in Jane Eyre. Everything in the external world is simply a projection of the internal world; "the narrator's conflict is externalized and embodied in the entire universe" (Auerbach 329). This again is inaccurate. Jane does not simply succumb to a passion which is part of her constitution, she falls in love with another being whose spirit she recognizes but cannot see in 
entirety, a being whom she is capable of being in conflict with, of leaving and returning to.

More importantly, Jane's rage in the story is not without external cause. Brontë sets up a situation full of good reasons for anger. Jane Eyre suffers the cruelty of Mrs. Reed and deprivation at the hands of Mr. Brocklehurst; and even Edward Rochester deceives and manipulates her. In addition, Jane, like her creator, is aware of her position as a woman in the world, and she is angered by it. She paces the hall of the third floor, longing for freedom. She asserts her spiritual equality with Mr. Rochester at a time when such an assertion would have been daring. In a well-known and often quoted passage she protests that "women feel just as men feel; they need exercise for their faculties, and a field for their efforts as much as their brothers do; they suffer from too rigid a constraint, too absolute a stagnation, precisely as men would suffer. ..." (Jane Eyre 128). Jane's anger, then, is catalyzed by external forces, and is in part political. By approaching the self in Jane Eyre as a pre-existing entity, Auerbach dismisses the influence of external forces and avoids the political content of the text.

Furthermore, like von Schmidt, Auerbach ends up evaluating this entity as a thing produced by the resolution of the conflict. The ideal to which the product-self is compared is implied in Auerbach's disappointment at the end of the novel. "Everything that Rochester represented was crushed," she writes, lamenting his newfound belief in the god that "has been an anti-life force throughout the novel. ..." (Auerbach 335). Rochester, then, represents Jane's life force, and this is the "good" part of her. He represents sexuality and rebellion and passion, and at the end of the story these are the things that Jane does not have enough of, according to Auerbach. Such a judgment is reductive and essentialist. It fails to appreciate, even to notice, the spiritual element of Jane and her relationship to Edward. Because of her inability to see the spiritual in the novel, Auerbach misses the significance of positive aspects of Jane and Edward's marriageespecially the politically important reign of spiritual equality at Ferndean. "My equal is here," Brontë has Edward say when he asks Jane to marry him (Jane Eyre 304).

In her article, "Two Crises of Decision in Jane Eyre," Maria Yuen seems to avoid passing judgment of Jane's self based on its quality as a finished product. She focuses on the two major decisions Jane makes in the course of the novel-her decision to leave Rochester and her later decision to refuse St. John and return to Rochester-and analyzes Jane's motivation. However, her analysis of motivation is flawed by her vision of the self as a determinate and pre-existing object. 
"I think the basic motivation underlying Jane's decision is ... the self," writes Yuen of the decision to leave Rochester. And later she says the decision was made "in self-interest" and for "self-protection" rather than for religious or moral reasons, or in order to conform to society (Yuen 215). I would have fewer problems with Yuen's argument if her vision of the self were less static-and if she took into account the relationship between self and society, but she does not. She agrees with Ruth Bernard Yeazell that Jane's "is a struggle to preserve the integrity and independence of the self"-assuming the pre-existence and autonomy of that self (Yuen 218). She goes on to argue that, for Jane, leaving Rochester is "a step towards ... the establishment of identity" (218). Jane's task, then, is a complex one; she must both protect her self-identity and find it. This puts her in the position of having to both protect something that does not exist and create something that already does. In any case, Yuen seems to believe that by the end of the novel, the self should be there, a whole and finished thing. And the decisions Jane makes are subject to judgment based on the ideal of the mature self and whether or not her decisions were made by or helped her to reach this ideal. What I find more troublesome about the ideal of the autonomous self in this essay is that it allows Yuen to avoid discussing the social and political context of the story. Charlotte Brontë was aware of the oppression of women, and she created characters that were also aware of it. Yet when Yuen analyzes the sources of Jane Eyre's fierce independence, she relies exclusively on Jane's personal history, primarily her experience as an orphan and the time she spent with the "ego-centric" Reeds (216). Jane Eyre, writes Yuen, feels cut off from the world, and this is both the cause and eventually the result of her independence. It is interesting that at one point Yuen, like von Schmidt, sees this independence as a lack of ability on Jane's part. "She is the centre of her own universe; she cannot relate spontaneously to other people...." (Yuen 216). Nowhere in the essay is Jane's position as a woman (or as a member of the semi-servant class of governess) taken into account in the development of the intense desire for independence that Yuen credits as motivating her decisions. Therefore, Jane's independence and isolation are seen as the somewhat unfortunate results of a bad childhood instead of as part of her rebellion against the inequality and oppressiveness of her position in society.

Sandra M. Gilbert and Susan Gubar do the best job of seeing Jane Eyre's self in a social context and so avoid many of the other reader/critics' problems. With Jane Eyre, the authors write, "the young novelist seems ... definitively to have opened her eyes to female realities within and around her" (Gilbert and Gubar 336). Jane 
begins her "progress towards maturity" according to Gilbert and Gubar, with the red room episode, for it is here she first sees herself and her position in the world. It is here she resolves to free herself, and she does so by telling the truth, by saying what "neither a Victorian child nor a Cinderella was ever supposed to be capable" of saying (343). The result is that Jane is literally freed from Gateshead.

She is sent to Lowood, Gilbert and Gubar explain, where she begins a new stage in her development. At Lowood, Jane's self continues the process of maturation largely through her association with Helen Burns and Miss Temple. Gilbert and Gubar agree with Adrienne Rich that Helen and Miss Temple are "mothers for Jane ... comforting her, counselling her, feeding her, embracing her." Both mothers contain "a 'sewer' of concealed resentment" and offer Jane models for "com[ing] to terms with her fate" (Gilbert and Gubar 346). But their ways are the thoroughly conventional ways of "ladylike repression" and "saintly renunciation," and Jane rejects them (347).

In their discussion of the first part of Jane Eyre, it is clear that Gilbert and Gubar do take social context into account. Indeed it is their main concern. Because of this, they are able to see things crucial to the development of the story that the other reader/critics miss. Maria Yuen, for example, does not see the importance of Jane Eyre's love for and rejection of Miss Temple and Helen Burns as role models, because she does not consider societal expectations that Jane be a Helen Burns or a Miss Temple. None of the other critics recognize the importance, furthermore, of the act of speakingspecifically, Jane's speaking out against the harsh treatment of Mrs. Reed-because they do not look at the act of speaking in the context of traditionally silent "Victorian children and Cinderellas." Gilbert and Gubar's analysis of the Gateshead and Lowood sections is already successful in a way the other texts are not.

The title of Gilbert and Gubar's section on Charlotte Brontë, "The Spectral Selves of Charlotte Brontë," suggests a number of things about the state of "self" in Brontë's work. To begin with, it suggests that it is divided-like a spectrum. Furthermore, it suggests that these selves or pieces of selves are ghostly, like specters, or unreal. In fact, Gilbert and Gubar find both a self that is splintered and resulting partial selves that are either from the world of ghosts and monsters, or are in some other way unreal.

The most obvious manifestation of the splintered self is Bertha Mason, the mad wife of Edward Rochester and the character to which the title of Gilbert and Gubar's book refers. That Bertha is not just a symbol but is Jane herself, or some part of Jane, is made clear, according to Gilbert and Gubar, in a number of passages-including 
the one in which Bertha makes her first appearance to Jane. Bertha "puts on the wedding veil intended for the second Mrs. Rochester, and turns to the mirror." Jane sees Bertha's face in the mirror "as if it were her own" (Gilbert and Gubar 362). More importantly, Bertha does what Jane would like to do. Each of her attacks follows an incident which might rightly have angered Jane. It is Bertha who prevents a wedding about which Jane has very serious doubts (359$60)$. And it is Bertha who causes Rochester's maiming, an event Jane herself "in disguised hostility" predicts (360). Bertha embodies Jane's angry self-her "mad" self.

Other, less threatening aspects of the spectral self are embodied by less frightening figures, write Gilbert and Gubar. There is, for example, the dream image of the "baby-phantom," representative of Jane's past self (358). Both Rochester and St. John are also seen by Gilbert and Gubar as aspects of Jane's fragmented self. St. John, as Auerbach has already pointed out, represents the icy part of Janethe part that belongs to control and the patriarchal structures of religion, the part that is self-sacrificing, that belongs to the world of Helen Burns and to death. Rochester is passion and sexuality (Gilbert and Gubar 366).

Gilbert and Gubar see this splintering of the self as a kind of sickness. That they are, in part, setting out to map a kind of pathology in the writings of nineteenth-century women is apparent in the title of the book, The Madwoman in the Attic, and is further expressed in some of the chapter titles: "The Infection in the Sentence," "The Secret Inward Wound." By suggesting that Brontë's splintered, "spectral" selves are unhealthy, Gilbert and Gubar reveal their assumption that there is another kind of self, a healthy, whole self. They suggest, furthermore, that this mature self is or should be the final destination of the main character. And, in fact, a healthy self is what Gilbert and Gubar decide Jane Eyre has at the end of her story. When "she escapes from [St. John's] fetters"-his proposal of marriage-she has come to the end of her pilgrimage. At that moment, she is "freed from the burden of her past, freed from both the raging specter of Bertha ... and from the self-pitying specter of the orphan child ..." (Gilbert and Gubar 368).

Gilbert and Gubar too believe in the self as a thing that can be achieved, the self-as-product. They do not question the ideal of the healthy self. In this way, they resemble the other reader/critics I have discussed. Unlike von Schmidt and Auerbach, however, Gilbert and Gubar accept the final version of Jane's self as "right" - the ideal or some version of the ideal. But how can Jane be freed from her past? How can she be freed from the anger that Bertha Mason represents? 
Or the "icy," religious part of her that St. John represents? Gilbert and Gubar's acceptance of Jane's self as mature, whole, healthy has problematic political implications. For one thing, as I have already pointed out, the creation or acceptance of ideals is the creation or acceptance of hierarchies. Also, notions of maturity, wholeness, etc., exist outside of material considerations, do not take historical and material context into account. Whatever Jane is, "whole" or not, "healthy" or not, is a function of her situation, her history, her position in the world.

The problem is both theoretical-we do not want to be part of a system that marginalizes and valorizes according to an ideal-and practical. The ideal of the healthy self relegates everything else to the realm of sickness. Since not many of us will inherit a fortune, find a long-lost "respectable" and loving family, or have our favorite (and necessarily male) lover miraculously humbled, few of us will ever find ourselves in a situation similar to Jane's at Ferndean. How can we be "whole" in the same way Jane is if we are not financially independent? If we are not able to ascend to the leisured class? If we do not find, in the end, that we are from a good and loving family? If we do not find our perfect lover? How will we know we have reached wholeness in the absence of these trappings? It seems unwise to me to accept this (or any) vision of maturity and wholeness since then we would have to label as sickness or immaturity whatever does not conform.

\section{WORKS CITED}

Auerbach, Nina. "Charlotte Brontë: The Two Countries." University of Toronto Quarterly 42.4 (1973): 328-42.

Brontë, Charlotte. Jane Eyre. New York: Dodd, 1946.

Gilbert, Sandra M. and Susan Gubar. Madwoman in the Attic: The Woman Writer and the Nineteenth-Century Literary Imagination. New Haven: Yale UP, 1979.

Schweickart, Patricinio P. "Reading Ourselves: Toward a Feminist Theory of Reading." Gender and Reading. Ed. Elizabeth A. Flynn and Patricinio Schweickart. Baltimore: Johns Hopkins UP, 1986: 31-62.

Von Schmidt, Helen. "The Dark Abyss, the Broad Expanse: Versions of the Self in Jane Eyre and Great Expectations." Dickens Quarterly 2.3 (1985): 84-91.

Yuen, Maria. "Two Crises of Decision in Jane Eyre." English Studies: 57 (1976): 21526. 